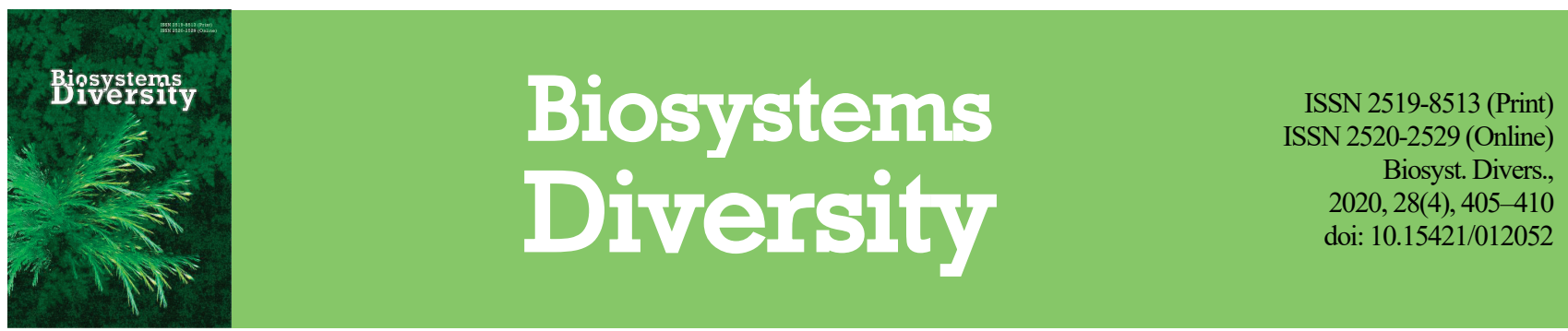

\title{
Change in the state of an exploited fish population: From individual indicators to integral assessment
}

\author{
E. I. Boznak*, V. G. Tereshchenko**, A. B. Zakharov* \\ *Institute of Biology of Komi Scientific Centre of the Ural Branch of the Russian Academy of Sciences, Russia \\ **Papanin Institute for Biology of Inland Waters, Russian Academy of Sciences, Borok, Russia
}

Article info

Received 20.09.2020

Received in revised form 12.102020

Accepted 13.10.2020

Institute of Biology of Komi Scientific Centre of the Ural Branch of the Russian Academy of Sciences, Tel.: +7-821-224-11-19. E-mail:

boznak@ib.komisc.ru

Papanin Institute for Biolog of Inland Waters, Russian Academy of Sciences, 152742, Russia.

Tel.: +7-485-472-40-42

E-mail:tervlad@ibiwru

\section{Boznak, E. I., Tereshchenko, V. G., \& Zakharov, A. B. (2020). Change in the state of an exploited fish population: From indivi- dual indicators to integral assessment. Biosystems Diversity, 28(4), 405-410. doi:10.15421/012052}

We adapted the approach used for the integral assessment of the status of ecosystems in order to assess population status. Classic theoretical concepts of fish population dynamics are the basis of this approach. The convolution of information about changes in several structural and functional characteristics into one integral index was performed using the analytical function of desirability. The index varied 0 to 1 and quantitatively characterizes the state of the population. This approach was tested on the example of the European grayling Thymallus thymallus (Linnaeus, 1758), inhabiting the Vym River (basin of the Northern Dvina River, North of the European part of Russia). The materials were collected during the environmental monitoring carried out by the Institute of Biology of Komi Science Centre of the Ural Branch of the Russian Academy of Sciences (IB FRC Komi SC UB RAS) in 2002, $2005-2019$. The population parameters used in the calculations (relative abundance; average and maximum age of fish; the proportion of matured individuals in the 4+ age group; average specific growth rate of fish at the age of 6+; body weight of fish in the age group 6+) were characterized on the basis of the control net catches. Compared with the period 2005-2006, the value of the integral index in 20152018 decreased by almost two times. This indicates deterioration in the condition of the grayling group in the study area. There were no serious disturbances in the fish habitat in this area. The main hydrochemical and hydrobiological indicators have not changed significantly. The main reason for the observed changes is likely the significant increase in the impact of recreational anglers. The proposed integral index may be useful both for assessing the state of fish populations and for developing measures for the rational management of fish stocks.

Keywords: condition; monitoring; European grayling; recreational fishing.

\section{Introduction}

Economic activity of humans inevitably exacerbates the impact on aquatic ecosystems. At the same time, there may be direct disturbance of water bodies and their drainage basins, as well as pressure from fishing. Therefore, it is necessary to check the condition of communities and populations of hydrobionts and evaluate changes in it. In the conditions of anthropogenic impact on fish populations, changes occur not only in such parameters as their mortality, recruitment rates, spatial, sex and age structures of individuals (rates of growth, maturation, etc.). Ultimately, this leads to increase in fluctuation of biomass (Hsieh et al., 2006) and decrease in productivity, negatively affecting stability, both of separate populations and the entire fish community (Barnet et al., 2017).

Currently, the strategy of management of aquatic biological resources and their protection in Russia and countries of the CIS is based on assessment of reserves and total allowable catch (TAC), which determines fishing quota and measures for the protection. Such approach works well if there are organized fishing and reliable data on exploited population. Necessary conditions for such assessments are multi-year continuous sequences of data concerning age composition of catches, catches per unit of industrial effort, tempo of linear growth and maturation of fish, and also average values of natural mortality coefficient for years and age groups (Babayan et al., 2018). Such an approach proved successful until the early 1990s, because the main users back then were collective enterprises or state structures with well developed accounting and monitoring of fish catch. However, because the number of users has increased, necessary data are often absent, while the reliability of available information is impossible to evaluate. Such a decrease in the amount of initial data limits the analysis at the level of production models (II level of information provi- sion) or imposes the need for using empirical, trend or other close methods (III level of information provision) (Babayan et al., 2018). The assessments obtained these ways are becoming more and more approximate. Moreover, during the assessments of stocks and TAC, the amounts of sport and illegal fishing, which may exceed the legal effort of fishing for some valuable industrial species, are not being taken into account (Zaporozhec et al., 2007).

In such situation, the alternative to determining reserves is complex assessment of the condition of populations, based on classic theoretical fundamentals on dynamics of the abundance and structure of fish populations (Nikol'skij, 1974; Ricker, 1979). Unfortunately, the traditional methods used to identify the population status allow only qualitative assessment, providing no option for quantitative assessment of the degree of its well-being. Furthermore, the parameters used to assess population (abundance, age structure, growth rates, etc.) often change in different directions. Integral indices which enrich bioindication studies performed using separate parameters allow practitioners to depict and, no less importantly, quantitatively assess the condition of the system. Thus the obtained results may be used when making management decisions oriented towards rational use of natural resources (Hovanov, 1996).

Integral parameters are broadly applied for assessing the condition of lake and river ecosystems (Tammi et al., 2006; Meng et al., 2009; Kuemmerlen et al., 2019), marine water areas (Liquete et al., 2013; Andersen et al., 2014), quality of surface waters (Gelashvili et al., 2006; Bikbulatov \& Stepanova, 2011; Voitenko \& Voitenko, 2017). However, at the population level, such an approach has not been employed until recently.

A convenient model of exploited population is the grayling Thymallus thymallus (Linnaeus, 1758) which lives in the upper reaches of the Vym River (the largest watercourse of the Middle Timan, which belongs 
to the basin of the Northern Dvina river). This ecologically flexible, coldloving and oxiphile species of fish is common in water bodies of the European part of Russia. It is characterized by relatively late maturation (4+$5+)$ and life expectancy of up to 15 years (Sidorov \& Reshetnikov, 2014). In most rivers of the Timan, grayling is the dominant species which determines the image of their fish assamblages. Its share in the survey catch accounted for $23.5-95.6 \%$. Sport fishing catches (spin fishing, float rods, artificial flies, etc.) may practically entirely be composed of grayling (Zakharov \& Boznak, 2019).

Logging and bauxite extraction sites located on the drainage basin of the Vym River have not led to notable improvements of the habitats of hydrobionts. The main anthropogenic factor taking effect on fish population is intense non-commercial (sport) fishing which causes re-structuring of the fish population and steady decrease in the number of industrially valuable fishes (Boznak et al., 2019).

The objective of this paper was the analysis of changes in the condition of grayling in the upper reach of the Vym River, in the conditions of long irrational exploitation, using the index of integral assessment.

\section{Materials and methods}

The study is built on the data collected during the monitoring of the conditions of fish in the upper reaches of the Vym River (basin of the Northern Dvina river) conducted by the Institute of Biology of Komi Science Centre of the Ural Branch of the Russian Academy of Sciences (IB FRC Komi SC UB RAS) in 2002, 2005-2019. Control catches were made in the summer-autumn period using standard sets of fixed gillnets with $20-40 \mathrm{~mm}$ cells. Throughout the study period, the construction, places of installations and regime of checking the nets remained the same. In total we examined 2,098 specimens of grayling caught in the monitoring plot of the main streambed of the upper reach of the Vym River.

Relative abundance of fish was determined as the amount of catch per effort, i.e. number of specimens captured in the $30 \mathrm{~m}$ long vertical panel of net over $24 \mathrm{~h}$ (specimens $/ 30 \mathrm{~m}$ of net per $24 \mathrm{~h}$ ) during 6-8 days (in the period from 10th to 30th of August of corresponding year).

Biological analysis was performed using the standard methods (Pravdin, 1966; Sidorov \& Reshetnikov, 2014). In all captured fish, we determined length (according to Smitt-FL) and body weight, sex and maturity stage. Age of fish was determined according to the scale collected from the first-second scale rows above the lateral line, behind the vertical line from the posterior margin of the dorsal fin. Linear growth of each individual was characterized using of back-calculations method according to formula by E. Lea (Pravdin, 1966):

$$
\mathrm{L}_{\mathrm{n}}=\frac{\mathrm{FL}}{\mathrm{R}} \times \mathrm{r}_{\mathrm{n}}
$$

where $L_{n}$ is body length calculated at the age $n ; F L$ - body length of fish at the moment of capturing; $\mathrm{R}-$ scale radius; $\mathrm{r}_{\mathrm{n}}$-radius of annual ring.

Specific growth rate was calculated using Schmalhausen-Brody formula (Mina \& Klevezal, 1976):

$$
\mathrm{C}=\frac{\lg l_{n}-\lg l_{0}}{0,4343 \times\left(t_{n}-t_{0}\right)}
$$

where $l_{n}$ - size of fish at the final moment of time $t_{n} ; l_{0}-$ size of fish at the initial moment of time $t_{0}$.

To reduce the error, the material was analyzed by one operator.

It has to be noted that diversity of current methods for describing the processes of transformation of natural systems could be conditionally divided into two groups: "assessment of condition" and "monitoring" (or analysis of dynamics of the system). Usually, within the framework of "assessment" approach, using a broad range of various indicators, current condition of studied ecosystem is compared to some etalon values (singletime assessment). It is more often applied for classification of water bodies, assessment of well-being of ecosystem and communities of hydrobionts (Tammi et al., 2006; Liquete et al., 2013; Andersen et al., 2014). "Monitoring" approach is more or less continuous observation based on standard methods of collection and analysis of initial information. Monitoring usually implies collection of a smaller amount of types of data (Pope et al., 2010) and is more often used for survey of dynamics of separate populations of fish (Quist, 2007; Vdovin \& Chernoivanova, 2006;
Anderson et al., 2008; Sguotti et al., 2019), rarer fish assamblages of water bodies of different types (Gido et al., 2000; Mercado-Silva et al., 2006; Orsi \& Britton, 2014). Ultimately, both of these approaches serve one goal - assessment of the condition of the system, to what extent its structure and functioning pattern have changed.

The problem of describing any complex system (including ecosystems, communities and populations) is complicated by the fact that it may be described by a broader set of parameters which vary in their dimentions. At the sametime, increases in some parameters may indicate improvement of the condition of the ecosystem, while changes in the other parameters may indicate occurring negative processes. One of the possible ways of solving this problem is convolution of information using various functions of desirability (Hovanov, 1996; Shitikov et al., 2003; Costa et al., 2011) or application of indices based on the similar principle (Olin et al., 2013; Andersen et al., 2014). In this study, we employed the method of integral assessment of the condition of ecosystem on the basis of simple analytical function of desirability, which we adapted to assess the condition of population.

The state of fish populations is known to be closely related to such characteristics as abundance and growth rate of population, linear growth and body weight growth of individuals, age and sex structures, etc (Nikol'skij, 1974; Ricker, 1979).

As the criteria that would describe the population, we used the following parameters, which we calculated using the data of control net capturing: relative abundance of population; average age of fish; maximum age; maturation rate (share of mature individuals in age group 4+); rate of linear growth (average specific growth rate of fish at the age of $6+$ from the second to sixth year of life); rate of body weight gain (body weight in fish of age group $6+$ ).

These parameters directly characterize the state of population, i.e. are not derivative from other parameters, and there is no strong correlation relationship between them (Table 1). The features we took for the analysis obviously describe the state of population in different ways. Growth of some parameters indicates its well-being (abundance, average age of fish in the catches, age limit, tempi of linear growth and weight gain) (Nikol'skii, 1974). Increase in the other parameters (maturation rate) may suggest increase in the pressure from fishing which provides a selective advantage of fast maturation of individuals (Borisov, 1978; Enberg et al., 2012).

The abovementioned parameters are size-based, which should be taken into account during the quantitative level of studies (Reshetnikov \& Tereshchenko, 2017). In order to make all parameters not size-based, we used one of "simple analytical functions of desirability" (Costa, 2011) in such a way that the best assessment for each criteria corresponded to the value 1 , while the worst one equaled 0 . Such an adjustment was calculated for the parameters of the first group using the formula:

$$
Y_{i}^{\prime}=\frac{x_{i}-x_{\min }}{x_{\max }-x_{\min }}
$$

For the parameters of the second group according to the formula:

$$
Y_{i}^{\prime}=\frac{x_{\max }-x_{i}}{x_{\max }-x_{\min }}
$$

where $Y_{i}^{\prime}$ is specific value of condition index, calculated according to parameter $\mathrm{i} ; \mathrm{x}_{\mathrm{i}}$ - current value of parameter; $\mathrm{x}_{\min }, \mathrm{x}_{\max }-$ minimum and maximum values of the parameter (Derringer \& Suich, 1980; Dmitriev, 2009; Costa, 2011).

To avoid subjectivity in selecting "etalon" values, as minimum and maximum values of the criteria, we took the highest and lowest values of the parameter for the entire period of the observations (2005-2019). As a result, the initial parameters were adjusted to non-size scales, and then integral index of condition of population (Q) may be obtained using them.

Currently, a whole number of synthesizing principles is used: principle of the worst status ("one out - all out") (Borja \& Rodríguez, 2010), different types of averaging (mean arithmetic, weighed arithmetic mean, geometric mean, etc.), total assessment or total rating, use of multimetric parameters, etc. (Borja et al., 2014).

In our case, absence of significant correlation between the parameters (Table 1) allows us to depict the studied population as a point in multi- 
dimensional space. Integral assessment of the condition in such a system would be its remoteness from the beginning of the coordinates (from point 0 , which corresponds to the worst status), reduced to the number of used parameters:

$$
Q=\frac{\sqrt{\sum_{i=1}^{m} Y_{i}^{\prime 2}}}{\sqrt{m}}
$$

where $Y_{i}^{\prime}$ is a specific value of the index, calculated according to parameter $\mathrm{i}, \mathrm{m}$ - number of used parameters.

\section{Results}

Relative abundance of grayling Th. thymallus in the upper reach of the Vym River throughout the survey period varied within the range of $0.81-6.77$ spec./24 hours (Fig. 1). The period of observed fluctuations in the abundance equaled around 4 years. At the same time, the value of abundance index calculated according to net catches may change by over 7 times over two subsequent years (2017-2018). Such a dysbalance in the values complicates the identification of tendencies of changes in the abundance. In our case, the analysis of data on abundance alone does not allow one to evaluate the change in the state of studied fish population.

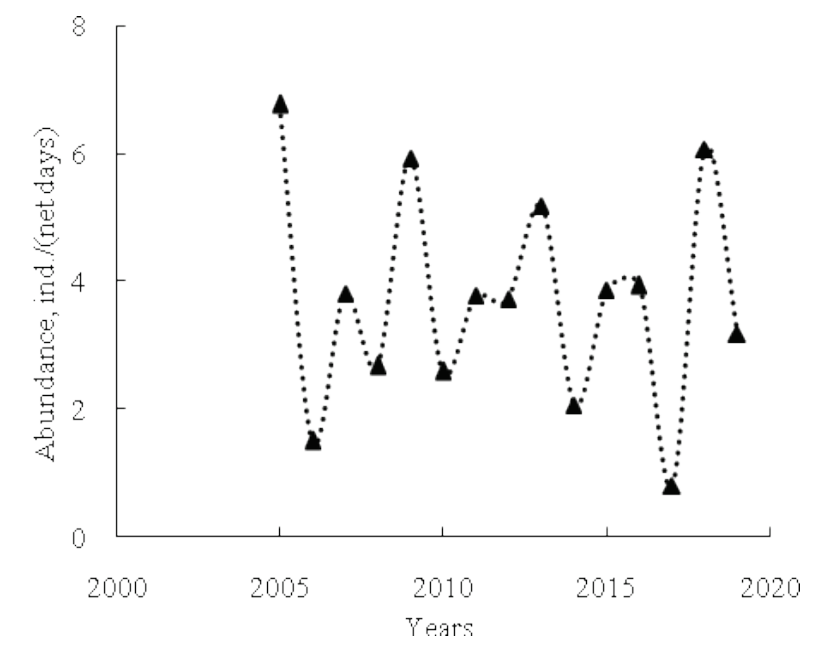

Fig. 1. Relative abundance of Thymallus thymallus in the upper reaches of the Vym River

\section{Table 1}

Values of the Spearman's rank correlation coefficients between the parameters used to assess the state of the Thymallus thymallus population in the upper reaches of the Vym River

\begin{tabular}{lcccccc}
\hline \multicolumn{1}{c}{ Parameters } & Abundance & Average age & $\begin{array}{c}\text { Maximum age } \\
\text { individuals at the age 4+ }\end{array}$ & $\begin{array}{c}\text { Proportion of mature } \\
\text { gpecific rate of linear } \\
\text { growth at the age 6+ }\end{array}$ & $\begin{array}{c}\text { Average body mass at } \\
\text { the age 6+ }\end{array}$ \\
\hline Abundance & - & 0.218 & 0.373 & 0.205 & 0.363 \\
Average age & - & - & 0.296 & -0.103 & -0.503 \\
Maximum age & - & - & - & -0.031 & 0.270 \\
Proportion of mature individuals at the age 4+ & - & - & - & - & 0.247 \\
Specific rate of linear growth at the age 6+ & - & - & - & - & 0.257 \\
Average body mass at the age 6+ & - & - & - & - & - \\
\hline
\end{tabular}

\section{Table 2}

The ratio of age groups in the control catches of Thymallus thymallus in the upper reaches of the Vym River (\%)

\begin{tabular}{|c|c|c|c|c|c|c|c|c|c|c|c|c|c|c|c|}
\hline Age & 2005 & 2006 & 2007 & 2008 & 2009 & 2010 & 2011 & 2012 & 2013 & 2014 & 2015 & 2016 & 2017 & 2018 & 2019 \\
\hline $1+$ & - & - & 3.3 & - & - & - & - & - & - & - & - & - & - & - & - \\
\hline $2+$ & 0.5 & - & - & - & - & 2.1 & 0.9 & 1.6 & - & 0.5 & - & 0.8 & - & 0.8 & - \\
\hline $3+$ & 3.7 & 8.0 & 10.0 & 7.4 & 6.6 & 29.2 & 7.0 & 50.6 & 10.4 & 11.1 & 4.7 & 27.2 & 11.5 & 49.6 & 11.5 \\
\hline $4+$ & 22.2 & 14.0 & 43.3 & 42.6 & 32.5 & 18.1 & 40.5 & 25.9 & 65.2 & 65.1 & 43.0 & 35.2 & 61.5 & 29.3 & 42.6 \\
\hline $5+$ & 60.3 & 32.0 & 3.3 & 38.2 & 44.8 & 23.6 & 16.7 & 12.4 & 10.9 & 22.2 & 40.4 & 24.8 & 19.2 & 17.9 & 24.6 \\
\hline $6+$ & 10.1 & 26.0 & 25.0 & 7.4 & 15.6 & 20.8 & 20.0 & 4.8 & 10.0 & 1.1 & 10.6 & 10.4 & 7.7 & 1.6 & 21.3 \\
\hline $7+$ & 1.6 & 2.0 & 13.3 & 2.9 & - & 5.6 & 9.8 & 2.4 & 1.5 & - & 0.9 & 1.6 & - & 0.8 & - \\
\hline $8+$ & 0.5 & - & 1.7 & 1.5 & - & - & 5.1 & 1.6 & 1.0 & - & 0.4 & - & - & - & - \\
\hline $9+$ & 0.5 & 18.0 & - & - & - & 0.7 & - & 0.4 & 0.5 & - & - & - & - & - & - \\
\hline $10+$ & - & - & - & - & - & - & - & 0.4 & 0.5 & - & - & - & - & - & - \\
\hline $11+$ & 0.5 & - & - & - & - & - & - & - & - & - & - & - & - & - & - \\
\hline Average & 4.9 & 5.7 & 4.8 & 4.6 & 4.7 & 4.5 & 5.0 & 3.9 & 4.3 & 4.1 & 4.6 & 4.2 & 4.2 & 3.7 & 4.6 \\
\hline
\end{tabular}

Table 3

Average specific rate of linear growth and average body mass of Thymallus thymallus at the age $6+$ in theVym River

\begin{tabular}{|c|c|c|c|c|c|c|c|c|c|c|c|c|c|c|c|}
\hline Parameters & 2005 & 2006 & 2007 & 2008 & 2009 & 2010 & 2011 & 2012 & 2013 & 2014 & 2015 & 2016 & 2017 & 2018 & 2019 \\
\hline Specific rate of linear growth, year ${ }^{-1}$ & 0.45 & 0.42 & 0.41 & 0.38 & 0.41 & 0.41 & 0.41 & 0.45 & 0.44 & 0.44 & 0.42 & 0.43 & 0.39 & 0.41 & 0.43 \\
\hline Average body mass, $\mathrm{g}$ & 442 & 454 & 394 & 368 & 318 & 339 & 332 & 370 & 406 & 329 & 341 & 445 & 343 & 451 & 387 \\
\hline
\end{tabular}

Table 4

Conversion of the initial data (x) into elementary well-being indices $\left(\mathrm{Y}^{\prime}\right)$ and calculation of the integral index (Q) of the population status of Thymallus thymallus in the upper reaches of the Vym River

\begin{tabular}{|c|c|c|c|c|c|c|c|c|c|c|c|c|c|c|c|c|}
\hline Parameters & & 2005 & 2006 & 2007 & 2008 & 2009 & 2010 & 2011 & 2012 & 2013 & 2014 & 2015 & 2016 & 2017 & 2018 & 2019 \\
\hline \multirow{2}{*}{ Abundance, ind./(net days) } & $\mathrm{x}$ & 6.8 & 2.8 & 3.8 & 2.7 & 5.9 & 2.6 & 3.8 & 3.7 & 5.2 & 2.1 & 3.9 & 3.9 & 0.8 & 6.1 & 3.2 \\
\hline & $\mathrm{Y}^{\prime}$ & 1.00 & 0.33 & 0.50 & 0.31 & 0.86 & 0.30 & 0.50 & 0.49 & 0.73 & 0.21 & 0.51 & 0.53 & 0.00 & 0.88 & 0.40 \\
\hline \multirow{2}{*}{ Average age, years } & $\mathrm{x}$ & 4.9 & 5.1 & 4.8 & 4.6 & 4.7 & 4.5 & 5.0 & 3.9 & 4.3 & 4.1 & 4.6 & 4.2 & 4.2 & 3.7 & 4.6 \\
\hline & $Y^{\prime}$ & 0.85 & 1.00 & 0.78 & 0.64 & 0.72 & 0.58 & 0.91 & 0.10 & 0.38 & 0.29 & 0.65 & 0.36 & 0.37 & 0.00 & 0.61 \\
\hline \multirow{2}{*}{ Maximum age, years } & $\mathrm{x}$ & 11 & 9 & 8 & 8 & 7 & 9 & 8 & 10 & 10 & 6 & 8 & 7 & 6 & 7 & 6 \\
\hline & $\mathrm{Y}^{\prime}$ & 1.00 & 0.60 & 0.40 & 0.40 & 0.20 & 0.60 & 0.40 & 0.80 & 0.80 & 0.00 & 0.40 & 0.20 & 0.00 & 0.20 & 0.00 \\
\hline \multirow{4}{*}{$\begin{array}{l}\text { Proportion of mature individuals } \\
\text { in the age } 4+, \% \\
\text { Specific rate of linear growth } \\
\text { in the age } 6+\text {, year }{ }^{-1}\end{array}$} & $\mathrm{x}$ & 64 & 66 & 69 & 66 & 44 & 50 & 62 & 60 & 93 & 73 & 83 & 62 & 50 & 83 & 92 \\
\hline & $Y^{\prime}$ & 0.59 & 0.55 & 0.49 & 0.56 & 1.00 & 0.88 & 0.63 & 0.68 & 0.00 & 0.41 & 0.21 & 0.63 & 0.88 & 0.20 & 0.02 \\
\hline & $\mathrm{x}$ & 0.45 & 0.42 & 0.41 & 0.38 & 0.41 & 0.41 & 0.41 & 0.45 & 0.44 & 0.44 & 0.42 & 0.43 & 0.39 & 0.41 & 0.43 \\
\hline & $Y^{\prime}$ & 1.00 & 0.55 & 0.40 & 0.00 & 0.50 & 0.45 & 0.46 & 0.99 & 0.80 & 0.81 & 0.61 & 0.68 & 0.24 & 0.49 & 0.70 \\
\hline \multirow{2}{*}{ Average body mass in the age $6+, \mathrm{g}$} & $\mathrm{x}$ & 442 & 454 & 394 & 368 & 318 & 339 & 332 & 370 & 406 & 329 & 341 & 445 & 343 & 451 & 387 \\
\hline & $Y^{\prime}$ & 0.91 & 1.00 & 0.56 & 0.37 & 0.00 & 0.15 & 0.10 & 0.38 & 0.65 & 0.08 & 0.17 & 0.93 & 0.18 & 0.98 & 0.50 \\
\hline \multicolumn{2}{|c|}{ Integral index of population well-being $(\mathrm{Q})$} & 0.90 & 0.72 & 0.54 & 0.43 & 0.65 & 0.55 & 0.56 & 0.64 & 0.63 & 0.40 & 0.46 & 0.60 & 0.41 & 0.58 & 0.46 \\
\hline
\end{tabular}


Age structure of the control net catches of grayling from the upper reaches of the Vym River was represented by individuals which belonged to 4-9 age classes. The oldest captured fish were 11 years old. At the same time, the proportion of age groups in the catches from different years significantly varied. It has to be noted that the value of this parameter may be affected by climatic conditions of the particular year (water level, weather conditions, etc.). Nonetheless, despite inter-year fluctuations, average share of individuals numerously caught over spawning (6+ and older) decreased from $33.1 \%$ (in 2005-2007) to $10.5 \%$ (in 2017-2019). At the same time, if in 2005-2007 maximum age of grayling ranged 8+-11+, in 2017-2019 it did not exceed $7+$ (Table 2). Thus, there is seen a stable tendency towards decrease in the average and maximum age of fish, caused by gradual decrease in the share of individuals of older age groups.

Mass maturation of grayling in the upper reaches of the Vym River occurs at the age of 4+-5+. Therefore, in 1996 and 2000, the earliest cases of maturation were observed in fish aged $4+$. Starting from 2002, in the control catches, mature individuals at the age $3+$ were found quite regularly. At the same time, if in 1996-2000, maturation was seen in 33.3-37.5\% of individuals aged 4+, starting from 2013 this indicator usually exceeded $70.0 \%$ (Fig. 3). The available data allows us to state a constant increase in maturation rate of grayling in the upper reaches of the Vym River.

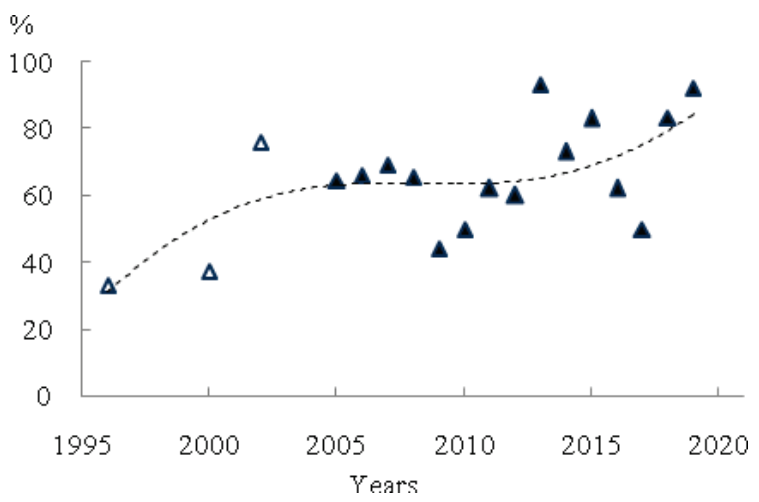

Fig. 2. The proportion of mature individuals in the age group 4+ of the Thymallus thymallus in the upper reaches of the Vym River: light triangles - data collected during preliminary research; solid triangles - data collected during continuous observations

Average specific rate of mature fish which took part in spawning more than once (age of $6+$ ) throughout the period of observations remained quite stable $(\mathrm{CV}=4.9 \%)$. Slightly greater variation was seen in mean body weight $(\mathrm{CV}=12.7 \%)$. This dynamic is likely to be caused by inter-year variability of fattening conditions. The available data do not allow us to determine any pattern in changes of these parameters (Table 3 ).

Adjustment of the initial data into specific indices of well-being ( $\left.\mathrm{Y}^{\prime}\right)$ and subsequent calculation of integral index $(\mathrm{Q})$ which unites the information obtained according to separate indicators allows us to unite the data on changes in separate population indicators. The value of integral index for the past 15 years (from 2005), which we calculated, decreased almost twice (Table 4), indicating significant deterioration of the condition of grayling population living in the upper reaches of the Vym River.

\section{Discussion}

The pProblem of complex assessment of such a complicated ecological level as population so far remains poorly developed. Usually, separate parameters used in practice reflect one of the aspects of its condition. Furthermore, different indicators used to characterize population have different types of dynamics. Uneven influence can be also placed on their values by weather factors, to a high degree determining the conditions of collecting field ichthyological material. All this should be taken into account when interpretting the obtained results.

Therefore, differently oriented changes in the population index may be related to the amount of precipitations which fell over the springsummer period, which in turn affects the spatial distribution of fish in the places of fattening, and accordingly their density. Detection of patterns of changes in the abundance, in this case, requires application of special methods of analysis (for examples, method of dynamic phase portrait of real biological system). Particularly, the analysis of dynamics of population which we performed earlier allowed us to draw a conclusion that after 2007 the grayling population in the Vym River transitioned into a new balanced condition with the level of abundance lower than in the early 2000s (Boznak et al., 2019). Such a decrease in the number can be considered as an indicator of deterioration of population status, though in this case, we have only qualitative assessment to use.

Change in the age structure of the catches that we described above (decrease in the average age and age limit) indicates stable deterioration of the condition of the grayling population in the upper reaches of the Vym River. Similar changes in general are distinctive for populations, the structure of which is affected by the selective catch of mature individuals. The dysbalance it causes to the stability of recruitment and remaining stock of fish (Nikol'skij, 1974) in turn may lead to decrease in the stability of the population.

Intense fishing may be considered as an additional selection factor which gives selective advantage to quickly maturing individuals (Borisov, 1978; Naish \& Hard, 2008; Enberg et al., 2012). Furthermore, thinningout of population can lead to increase in the food provision, which in turn can cause increase in the growth rate and earlier maturation (Nikol'skij, 1974; Kotenev et al., 2009). Thus, increase in the maturation rate in the conditions of relative stability of the food base of fish in general indicates deterioration of the status of the grayling population in the upper reaches of the Vym River. Therefore, even according to several parameters, one may qualitatively describe the condition of the system ("well - bad") and the direction of its change ("better-worse").

Implementation of indices which integrate the data on the condition of the system provides a transition from qualitative to quantitative description. At the same time, different size-base values of parameters of population are adjusted into non size-based specific indices of well-being, which could be easily combined if needed. Such an approach of adjustment of data has a number of advantages.

The variant of integral well-being index of population used in this survey allows for analysis of the parameters in the multi-dimensional space, from the beginning of coordinates, i.e. the worst condition of population for the entire period of observation $(\mathrm{Q}=0)$ to the point which corresponds to a particular moment of time. As a result, we determined the worst general condition of population of grayling in the Vym River, occurring in 2005-2019.

This approach allows one to determine the borders of the zones of condition of population which differ by levels of well-being. In the condition of balance, fluctuations of most parameters that describe population are considered not to exceed one standard deviation $(\mathrm{m} \pm \mathrm{SD})$. Values beyond the borders of this range signal changes in the condition of population (Petitgas, 2009). Therefore, the full range of values of integral index of the condition may be divided into three regions: "conditionally well" condition $(\mathrm{Q}>\mathrm{m}+\mathrm{SD})$, "bad condition" (close to critical) $(\mathrm{Q}<\mathrm{m}-\mathrm{SD})$, and zone of "tension condition" located between them $(\mathrm{m}-\mathrm{SD}<\mathrm{Q}<$ $\mathrm{m}+\mathrm{SD})$.

During the greater part of the period of observations (in 2007-2019), the value of the condition index $(\mathrm{Q})$ of grayling population in the upper reaches of the Vym River did not infringe the standard deviation from the mean multi-year values $(0.57 \pm 0.13)$. Thus, at the beginning of continuous observations (2005), the grayling population in the upper reaches of the Vym River was in favourable condition (relatively high abundance, insignificantly dysbalanced age structure, etc.). Then, since 2007 up to now, its status is considered "tense".

Gradual deterioration of the condition of the populations raises concerns. Actually, over the recent years, there was seen a decrease in the integral index of well-being of the population. At the same time, the values are close to the border between the zones of "tense" and "unfavourable" conditions. These changes theoretically could have been triggered by natural, as well as anthropogenic factors. However, no significant damages to the condition of the environment of fish in the upper reaches of the Vym River were found. Currently, the environment is damaged locally. The food base of the fish is stable: species composition and biomass are within the borders of climatic norm, and fish which live in the area are characterized by linear growth (Zakharov \& Boznak, 2019). Therefore, the main reason for deterioration of the condition of grayling, expressed in 
rejuvenation of its population, is likely the increase in sport (noncommercial) fishing. Increase in the amounts of fishing is hard to estimate quantitatively. However, in the early 2000s, in the upper reaches of the Vym River, hunting and fishing grounds operated, and now at least 6 such bases operate. Total length of the sites officially assigned to organization of sport fishing increased from 20 to almost $130 \mathrm{~km}$. Furthermore, development of the system of transport communications and increase in technical equipment of fishermen have led to increase in illegal fishing throughout the Central Timan. All of this suggests that the amounts of fishing over this period has increased by several times (Zakharov \& Boznak, 2019).

\section{Conclusions}

An integral index based on analytical function of desirability may be effectively applied to assess the condition and monitor changes occurring at the population level. This approach allows practitioners to integrate data obtained based on specific population characteristics, and quantitatively assess occurring changes. On the example of grayling in the upper reaches of the Vym River, the study shows that increase in the impact of sport fishing leads to changes in structural and functional characteristics, causing general decrease in "well-being level" of the exploited fish population. The method we suggested is being implemented during development and making of administrative decisions oriented towards protection and rational use of natural resources.

This study was performed within the framework of Ministry of Science and Higher Education of the Russian Federation State Task No. AAAA-A17-117112850235-2 and State Task No. AAAA-A18-118012690102-9.

\section{References}

Andersen, J. H., Dahl, K., Göke, C., Hartvig, M., Murray, C., Rindorf, A., Skov, H., Vinther, M., \& Korpinen, S. (2014). Integrated assessment of marine biodiversity status using a prototype indicator-based assessment tool. Frontiers in Marine Science, 2014, 55, 1-8.

Anderson, C. N., Hsieh, C. H., Sandin, S. A., Hewitt, R., Hollowed, A., Beddington, J., May, R. M., \& Sugihara, G. (2008). Why fishing magnifies fluctuations in fish abundance. Nature, 452, 835-839.

Babayan, V. K., Bobyrev, A. E., Bulgakova, T. I., Vasil'ev, D. A., Il'in, O. I., Kovalev, Y. A., Mihajlov, A. I., Miheev, A. A., Petuhova, N. G., Safaraliev, I. A., Chetyrkin, A. A., \& Sheremet'ev, A. D. (2018). Metodicheskie rekomendacii po ocenke zapasov prioritetnyh vidov vodnyh biologicheskih resursov [Methodological recommendations for the assessment of stocks of priority types of aquatic biological resources]. Izdatel'stvo Vserossijskogo Nauchno-Issledovatel'skogo Instituta Rybnogo Hozjajstva i Okeanografii, Moscow (in Russian).

Barnett, L. A., Branch, T. A., Ranasinghe, A. R., \& Essington, T. E. (2017). OldGrowth Fishes Become Scarce under Fishing. Current Biology, 27, 2843-2848.

Bikbulatov, E. S., \& Stepanova, I. E. (2011). Harrington's desirability function for natural water quality assessment. Russian Journal of General Chemistry, 81(13), $2694-2704$.

Borisov, V. M. (1978). Selekcionnoe vliyanie promysla na strukturu populyacii dlinnociklovyh ryb [The selective effect of fishing on the structure of the long-cycle fish population]. Voprosy Ikhtiologii, 18(3), 1010-1019 (in Russian).

Borja, Á., \& Rodríguez, J. G. (2010). Problems associated with the 'one-out, all-out' principle, when using multiple ecosystem components in assessing the ecological status of marine waters. Marine Pollution Bulletin, 60(8), 1143-1146.

Borja, A., Prins, T., Simboura, N., Andersen, J. H., Berg, T., Marques, J. C., Neto, J. M., Papadopoulou, N., Reker, J., Teixeira, H., \& Uusitalo, L. (2014). Tales from a thousand and one ways to integrate marine ecosystem components when assessing the environmental status. Frontiers in Marine Science, 1(72), 1-20.

Boznak, E. I., \& Zaharov, A. B. (2019). Sovremennoe sostoyanie i dinamika populyacionnyh pokazatelej evropejskogo hariusa Timanskogo vodotoka v usloviyah nereguliruemogo rybolovstva [The current state and dynamics of population parameters of the European grayling from the Timan watercourse in the bauxite deposit development area]. Vestnik Insituta Biologii Komi NC UrO RAN, 211, 29-35 (in Russian).

Boznak, E. I., Zakharov, A. B., \& Tereshchenko, V. G. (2019). Effect of the increasing intensity of recreational fishing on the fish assemblage of a watercourse in an economic development zone. Inland Water Biology, 12(1), 88-95.

Costa, N. R., Lourenço, J., \& Pereira, Z. L. (2011). Desirability function approach: A review and performance evaluation in adverse conditions. Chemometrics and Intelligent Laboratory Systems, 107(2), 234-244.
Derringer, G., \& Suich, R. (1980). Simultaneous optimization of several response variables. Journal of Quality Technology, 12, 214-218.

Dmitriev, V. V. (2009). Opredelenie integral'nogo pokazatelya sostoyaniya prirodnogo ob'ekta kak slozhnoj sistemy [Determination of the integral indicator of the state of a natural object as a complex system]. Obshchestvo, Sreda, Razvitie, 13, 146-165 (in Russian).

Enberg, K., Jørgensen, C., Dunlop, E. S, Varpe, Ø., Boukal, D. S., Baulier, L., Eliassen, S., \& Heino, M. (2012). Fishing-induced evolution of growth: Concepts, mechanisms and the empirical evidence. Marine Ecology, 33, 1-25.

Gelashvili, D. B., Korolev, A. A., \& Basurov, V. A. (2006). Zonirovanie territorii po stepeni nagruzki stochnymi vodami s pomoshch'yu obobshchyonnoj funkcii zhelatel'nosti (na primere Nizhegorodskoj oblasti) [Territory zonation by the degree of sewage loading with the aid of a generalized function of desirability (with the Nizhniy Novgorod region as an example)]. Povolzhskiy Joumal of Ecology, 2/3, 129-138 (in Russian).

Gido, K. B., Matthews, W. J., \& Wolfinbarger, W. C. (2000). Long-term changes in a reservoir fish assemblage: Stability in an unpredictable environment. Ecological Applications, 10(5), 1517-1529.

Hovanov, N. V. (1996). Analiz i sintez pokazatelej pri informacionnom deficite. [Analysis and synthesis of indicators in case of information deficit]. Izdatel'stvo Sankt-Peterburgskogo Universiteta, Saint-Petersburg (in Russian).

Hsieh, C. H., Reiss, C. S., Hunter, J. R., Beddington, J. R., May, R. M., \& Sugihara, G. (2006). Fishing elevates variability in the abundance of exploited species. Nature, 443, 859-862.

Kotenev, B. N., Kuznetsova, E. N., \& Bondarenko, M. V. (2009). Investigation of age composition and growth of cod Gadus morhua morhua of the Barents Sea in connection with the estimation of its stocks state. Journal of Ichthyology, 49(1), 47-55.

Kuemmerlen, M., Reichert, P., Siber, R., \& Schuwirth, N. (2019). Ecological assessment of river networks: From reach to catchment scale. Science of the Total Environment, 650, 1613-1627.

Liquete, C., Piroddi, C., Drakou, E. G., Gurney, L., Katsanevakis, S., Charef, A., \& Egoh, B. (2013). Current status and future prospects for the assessment of marine and coastal ecosystem services: A systematic review. PLoS One 8(7), e67737.

Meng, W., Zhang, N., Zhang, Y., \& Zheng, B. (2009). Integrated assessment of river health based on water quality, aquatic life and physical habitat. Journal of Environmental Sciences, 21(8), 1017-1027.

Mercado-Silva, N., Lyons, J., Díaz-Pardo, E., Gutiérrez-Hernández, A., Ornelas-García, C. P., Pedraza-Lara, C., \& Zanden, M. J. (2006). Long-term changes in the fish assemblage of the Laja River, Guanajuato, Central Mexico. Aquatic Conservation Marine and Freshwater Ecosystems, 16, 533-546.

Mina, M. V., \& Klevezal, G. A. (1976). Rost zhivotnyh [The growth of animals]. Nauka, Moscow (in Russian)

Naish, K. A., \& Hard, J. J. (2008). Bridging the gap between the genotype and the phenotype: Linking genetic variation, selection and adaptation in fishes. Fish and Fisheries, 9, 396-422.

Nikol'skij, G. V. (1974). Teoriya dinamiki stada ryb kak biologicheskaya osnova ratsional'noj ekspluatatsii i vosproizvodstva rybnykh resursov [The theory of fish school dynamics as a biological basis of sustainable use and reproduction of fish resources]. Pishchevaya Promyshlennost', Moscow (in Russian).

Olin, M., Rask, M., Ruuhijärvi, J., \& Tammi, J. (2013). Development and evaluation of the Finnish fish-based lake classification method. Hydrobiologia, 713, $149-166$.

Orsi, M. L., \& Britton, J. R. (2014). Long-term changes in the fish assemblage of a neotropical hydroelectric reservoir. Journal of Fish Biology, 84, 1964-1970.

Petitgas, P. (2009). The CUSUM out-of-control table to monitor changes in fish stock status using many indicators. Aquatic Living Resource, 22(2), 201-206.

Pope, K. L., Lochmann, S. E., \& Young, M. K. (2010). Methods for assessing fish populations. Nebraska Cooperative Fish \& Wildlife Research Unit - Staff Publications.

Pravdin, I. F. (1966). Rukovodstvo po izucheniyu ryb [Guide to the study of fish]. Pishchevaya Promyshlennost', Moscow (in Russian).

Quist, M. C. (2007). An evaluation of techniques used to index recruitment variation and year-class strength. North American Journal of Fisheries Management, 27, $30-42$.

Reshetnikov, Y. S., \& Tereshchenko, V. G. (2017). Quantitative level of research in fish ecology and errors associated with it. Russian Journal of Ecology, 48(3), 233-239.

Ricker, W. E. (1975). Computation and interpretation of biological statistics of fish populations. Bulletin 191. Fisheries Research Board of Canada, Ottawa.

Sguotti, C., Otto, S. A., Frelat, R., Langbehn, T. J., Ryberg, M. P., Lindegren, M., Durant, J. M., Stenseth, N. C., \& Möllmann, C. (2019). Catastrophic dynamics limit Atlantic cod recovery. Proceedings of the Royal Society B, 286, 2018-2877.

Shitikov, V. K., Rozenberg, G. S., \& Zinchenko, T. D. (2003). Kolichestvennaya gidroekologiya: Metody sistemnoj identifikacii [Quantitative hydroecology: Methods of systemic identification]. Institut Ekologii Volzhskogo Basseyna RAN, Togliatti (in Russian). 
Sidorov, G. P., \& Reshetnikov, Y. S. (2014). Lososeobraznye ryby vodoemov evropejskogo Severo-Vostoka [Salmoniformes fish in the ponds of the European Northeast]. Tovarishchestvo Nauchnyh Izdanij KMK, Moscow (in Russian).

Tammi, J., Rask, M., \& Ala-Opas, P. (2006). Ecological classification of Finnish lakes using a multimetric fish index. Internationale Vereinigung für Theoretische und Angewandte Limnologie, 29(5), 2276-2278.

Vdovin, A. N., \& Chernoivanova, L. A. (2006). Long-term dynamics of certain parameters of pacific herring Clupea pallasii (Clupeidae) in the Peter the Great Bay. Journal of Ichthyology, 46(1), 50-57.
Voitenko, L., \&, Voitenko, A. (2017). Integrated assessment of irrigation water quality based on Harrington's desirability function. International Journal of Agriculture Environment and Food Sciences, 1(1), 55-58.

Zakharov, A. B., \& Boznak, E. I. (2019). Rybnoe naselenie vodotokov Timana [Fish population of Timan watercourses]. Federal'nyy Issledovatel'skiy Tsentr Komi Nauchnyy Tsentr Ural'skogo Otdeleniya RAN, Syktyvkar (in Russian).

Zaporozhec, O. M., Shevlyakov, G. V., Zaporozhec, G. V., \& Antonov, N. P. (2007). Vozmozhnosti ispol'zovaniya dannyh o nelegal'nom vylove tihookeanskih lososej dlya real'noj ocenki ih zapasov [The use of the data on the illegal catches of pacific salmon in the prognostic researches]. Voprosy Rybolovstva, 31, 471483 (in Russian). 